\title{
Notices from the Public Policy Committee
}

\section{Department of Health circular regarding amendment to paragraph 2.6 of the \\ Code of Practice issued under section 118 of the Mental Health Act 1983}

The Public Policy Committee wishes to draw to the attention of members the Department of Health circular (dated 18 February 1992) regarding amendment to paragraph 2.6 of the Code of Practice issued under section 118 of the Mental Health Act 1983.

This amendment means that the doctor needs to consider the health or safety of the patient, or the prevention of harm to others, rather than the health and safety, as was the impression given by the Code of Practice.

There has been much concern about possible misinterpretation in this area, and the National Schizophrenia Fellowship has made a paper available to the College detailing the development of problems. A copy of this paper is available on written request from the Public Policy Committee.

\section{'Responsibility for Prescribing between Hospitals and General Practitioners'}

(NHS Management Executive circular EL (91) 127)

The Public Policy Committee wishes to draw to the attention of members the NHS Management Executive circular, EL (91) 127, dated 1 November 1991, Responsibility for Prescribing between Hospitals and General Practitioners. Possible problem areas include prescribing with psychiatric day-patients, or those under community psychiatric nurse follow-up, and the Committee recommends that members should ensure that appropriate arrangements are agreed with local general practitioner colleagues, through local Medical Committees, for adoption by Family Health Service Authorities.

Dr R. G. JoNES

Honorary Secretary Public Policy Committee

\section{Miscellany}

\section{New publications}

Examining Torture Survivors. This reference book contains adapted lectures from a working seminar held by the Danish Medical Group in September 1987 and is edited by Henrik Marcussen and Ole Vedel Rasmussen. It is published by the International Rehabilitation Council for Torture Victims (IRCT), Copenhagen, and the Danish Medical Group, Amnesty International, Juliane Mares Vej 34, DK-2100 Copenhagen O, Denmark.

East European Medical Journal is a multidisciplinary scientific journal in English devoted to specific health care problems in East Europe and Eurasia. Further information: East European Medical Journal, Eurocip, PO Box 209, 6600 Iasi 1, Romania.

The first advice book for Asian carers of elderly people in the UK Call for Care has been published by the Health Education Authority and the King's Fund Centre Carers Unit. It costs $£ 1.95$, plus 60p postage and packing and is a vailable in English, Urdu, Gujarati and Punjabi. A Bengali version is in preparation. Cheques should be made payable to the Health Education Authority and sent to Distribution
Department, Health Education Authority, Hamilton House, Mabledon Place, London WCIH 9TX.

The Audit Commission have recently published The Community Revolution: Personal Social Services and Community Care. Copies can be obtained from HMSO, price $£ 8.50$. HMSO publications are available from: HMSO Publications Centre (mail and telephone orders only) PO Box 276, London SW8 5DT (telephone orders 071873 0909; general enquiries 0718730011 ).

\section{Call for papers}

The Journal of Mental Health Administration (JMHA), the official publication of the Association of Mental Health Administrators, is seeking manuscripts on new developments, innovations, and trends in the management of mental health, substance abuse and related behavioural health and disability programmes. To be considered for publication, papers should be sent to: Dr Bruce Lubotsky Levin, Editor, The Journal of Mental Health Administration, Florida Mental Health Institute, University of South Florida, 13301 Bruce B. Downs Blvd., Tampa, Florida 33612-3899, USA (telephone 813974 4500); further information can be obtained from Carolyn S. Martinez, Editorial Associate, at the same address. 